\title{
FFA Study on Activity Concentration of Natural Radionuclides of Building Mate- rials in Pachal, Tiruvannamalai dist, Tamilnadu, India
}

\author{
Y.Raghu', N.Harikrishnan ${ }^{2}$, A.Chandrasekaran ${ }^{3}$, B.Govardhanan ${ }^{4}$ and R.Ravisankar $^{2 *}$ \\ ${ }^{1}$ Department of Physics, Aarupadai Veedu Institute of Technology, Paiyanoor- 603 104, Chennai, Tamilnadu, India. \\ ${ }^{2}$ Department of Physics, Government Arts College, Thiruvanamalai-606603, Tamilnadu, India. \\ ${ }^{3}$ Department of Physics, Vel Tech (Owned by RS Trust) Avadi, Chennai-600 062, Tamilnadu, India. \\ ${ }^{4}$ Department of Physics, Peri Institutie of Technology, Mannivakkam, Chennai - 600 048, Tamilnadu, India.
}

\section{Received Date: November 9, 2014 \\ Accepted Date: January 27, 2015 \\ Published Date: January 31, 2015}

*Corresponding authors: Ravisankar, R, Department of Physics, Peri Institutie of Technology, Mannivakkam, Chennai, Tamilnadu, India; Tel: 0993520534/ 9840807356; E-mail: ravisankarphysics@gmail.com

Citation: Ravishankar, R., et al. FFA Study on Activity Concentration of Natural Radionuclides of Building Materials in Pachal, Tiruvannamalai dist, Tamilnadu, India. (2015) J Environ Health Sci 1(1): 1-5.

Keywords: Building Materials; Gamma Ray Spectrometry; Radiological Hazards

\section{Introduction}

Man is continuously exposed to ionizing radiation from naturally occurring radioactive materials. These ionizing radiations coming from building materials, air, water and food. Measurement of activity concentrations of radionuclides in building materials is important in the assessment of population exposures, as most individuals spend $80 \%$ of their time indoors. A knowledge of natural radioactivity in man and its environment is important since naturally occurring radionuclides are the major source of radiation exposure to man. An established fact that all the construction material contains trace amount of natural radioactivity. This activity in a major source of external and internal radiation exposure to the occupants of the dwelling. The natural radioactivity in soil and building materials come mainly from uranium $\left({ }^{238} \mathrm{U}\right)$ and thorium $\left({ }^{232} \mathrm{Th}\right)$ series and the radioactive isotope of potassium $\left({ }^{40} \mathrm{~K}\right)$. All these can be sources of both internal and external radiation exposure. Internal exposure occurs through inhalation of radon gas and external exposure occurs through the emission of penetrating gamma rays. Therefore, it is important to measure the radioactivity levels in the built-up areas to assess the radiological consequences. Even more important is the knowledge of the amount of natural activity present in the materials which are used in the construction of dwellings. The amount of activity present in building materials will decide its use in the construction of dwellings. The natural radioactivity of building materials in many countries has been reported ${ }^{[1-12]}$. Natural radioactivity in some Indian building materials has also been reported by other authors ${ }^{[6,11-15]}$. A knowledge of radioactivity present in construction materials helps to (a) assess the possible radiological hazards to human health and (b) develop the standards and guidelines for use and management of these materials. The present study was undertaken with the purpose of determining radioactivity in some building materials from Pachal of Tiruvannamalai District, Tamilnadu and assessing the radiological hazards due to external gamma ray exposure in dwellings.

\section{Methods of Measurements}

Sampling and Preparation: Samples representing five different commonly used building materials were collected randomly from sites where housing and other buildings were under construction and from building material suppliers in Pachal Village for the measurement of the specific radioactivity of ${ }^{226} \mathrm{Ra},{ }^{232} \mathrm{Th}$ and ${ }^{40} \mathrm{~K}$. Structural building materials (cement, brick, clay, sand and soil) are used in bulk amounts. The collected samples were kept in polyethylene bags which were numbered and catalogued for identification. The samples were brought to the sample preparation section of the low-level activity measurement laboratory. The brick samples were crushed, ground, and pulverised to a powder. The powder was passed through a sieve of 150 micron mesh size. The samples in powder form were dried at $110^{\circ} \mathrm{C}$ in a temperature-controlled furnace until there was no detectable change in the mass of the sample. The samples were transferred to radon-impermeable plastic containers of $6 \mathrm{~cm}$ diameter and $6.5 \mathrm{~cm}$ height. Then these samples were sealed and the sealed containers were left for at least 4 weeks ( $>7$ half-lives

Copy rights: (C2015 Ravishankar R. This is an Open access article distributed under the terms of Creative Commons Attribution 4.0 International License. 
of ${ }^{222} \mathrm{Rn}$ ) before counting by gamma ray spectrometry in order to ensure that the daughter products of ${ }^{226} \mathrm{Ra}$ up to ${ }^{210} \mathrm{~Pb}$ and ${ }^{228} \mathrm{Th}$ up to ${ }^{208} \mathrm{~Pb}$ achieve equilibrium with their respective parent radio nuclides ${ }^{[11]}$. Their respective net weights were measured and recorded with a high sensitive balance.

\section{Gamma spectrometry analysis of samples}

A 3"x 3" NaI (Tl) scintillation detector has been used for spectral measurements to enable one to cover the energy spectrum of the naturally occurring radio nuclides up to 2.6 $\mathrm{MeV}\left({ }^{208} \mathrm{Tl}\right.$, a daughter product of $\left.{ }^{232} \mathrm{Th}\right)$. The detector is shielded by $15 \mathrm{~cm}$ thick lead on all sides, including the top to reduce background due to cosmic ray component by almost $98 \%$. The inner sides of the lead shielding is lined with $2 \mathrm{~mm}$ thick Aluminium. Standard sources of the primordial radio nuclides obtained from IAEA in the same geometry and having the same density, as that of the prepared soil samples, were used to determine the efficiency of the detector for various energies in the prescribed geometry. The prepared samples were placed on top of the 3"x3" NaI (Tl) detector and using the gamma ray spectrometer and multichannel analyzer, count spectra were obtained for each of the building material samples. The activity content of the three primordial radio nuclides viz, ${ }^{40} \mathrm{~K},{ }^{232} \mathrm{Th}$ and ${ }^{226} \mathrm{Ra}$ are deduced from the count spectra. The region under the peaks corresponding to $1.46 \mathrm{MeV}\left({ }^{40} \mathrm{~K}\right), 1.764 \mathrm{MeV}\left({ }^{214} \mathrm{Bi}\right)$ and 2.614 $\mathrm{MeV}\left({ }^{208} \mathrm{Tl}\right)$ energies are considered to arrive at the radioactivity levels of ${ }^{40} \mathrm{~K},{ }^{226} \mathrm{Ra}$ and ${ }^{232} \mathrm{Th}$, respectively. The minimum detectable activity (MDA) of each of the three primordial radio nuclides is determined from the background radiation spectrum obtained for the same counting time as was done for the samples and is estimated at $2.15 \mathrm{~Bq} / \mathrm{kg}$ for ${ }^{232} \mathrm{Th}, 2.22 \mathrm{~Bq} / \mathrm{kg}$ for ${ }^{238} \mathrm{U}$ and $8.83 \mathrm{~Bq} / \mathrm{kg}$ for ${ }^{40} \mathrm{~K}$. All the building materials were subjected to gamma ray spectral analysis with a counting time of 20,000 s.

\section{Results and Discussion}

Radionuclide concentrations: Table 1 showed that the average radionuclide concentrations of ${ }^{226} \mathrm{Ra},{ }^{232} \mathrm{Th},{ }^{40} \mathrm{~K}$ and the radium equivalent activity beside the calculated criteria formula, total absorbed dose rate $\left(D_{R}\right.$ in $\left.n G y / h\right)$, annual effective dose rate (in $\mathrm{mSv} / \mathrm{y})$ the external hazard index $\left(\mathrm{H}_{\mathrm{ex}}\right)$ and the internal hazard index $\left(\mathrm{H}_{\mathrm{in}}\right)$ for the investigated in the samples. It can be seen from the table 1 that the potassium isotope contributes more activity compared with other two isotopes. The lowest value of ${ }^{226} \mathrm{Ra}$ concentration is $7.47 \mathrm{~Bq} / \mathrm{kg}$ measured in sand while the highest value is $31.26 \mathrm{~Bq} / \mathrm{kg}$ measured in cement. The lowest value for ${ }^{232} \mathrm{Th}$ is $27.09 \mathrm{~Bq} / \mathrm{kg}$ recorded in sand sample and the highest value is $77.8 \mathrm{~Bq} / \mathrm{kg}$ obtained in clay sample. The lowest and highest values for ${ }^{40} \mathrm{~K}$ were measured to be $233.92 \mathrm{~Bq} / \mathrm{kg}$ and $419.7 \mathrm{~Bq} / \mathrm{kg}$ in cement and soil respectively. The distribution of ${ }^{226} \mathrm{Ra},{ }^{232} \mathrm{Th}$ and ${ }^{40} \mathrm{~K}$ in building materials is not uniform. To monitor the radioactivity levels of a new building and construction materials, different radiological indices of these materials should be determined.
Table 1:Activity concentration, Radium equivalent Activity $\left(\mathrm{Ra}_{\mathrm{eq}}\right)$, Criteria formula (CF) Absorbed Dose Rate $\left(D_{R}\right)$ Annual Effective Dose rate $\left(H_{R}\right)$, Internal and External radiation hazard indices $\left(\mathrm{H}_{\mathrm{in}} \& \mathrm{H}_{\mathrm{ex}}\right.$ used in Pachal, Tiruvannamali Dist, Tamilnadu

\begin{tabular}{|c|c|c|c|c|c|c|c|c|c|c|}
\hline \multirow{2}{*}{$\begin{array}{l}\text { S. } \\
\mathrm{N} \\
\mathrm{o}\end{array}$} & \multirow{2}{*}{$\begin{array}{l}\text { Mate- } \\
\text { rial }\end{array}$} & \multicolumn{3}{|c|}{$\begin{array}{l}\text { Activity concentration } \\
\qquad(\mathrm{Bq} / \mathrm{kg})\end{array}$} & \multirow{2}{*}{$\begin{array}{l}\mathrm{Ra}_{\text {eq }} \\
(\mathrm{Bq} / \\
\mathrm{kg})\end{array}$} & \multirow{2}{*}{$\begin{array}{l}\text { Cri- } \\
\text { teria } \\
\text { for- } \\
\text { mula } \\
\text { (CF) }\end{array}$} & \multirow{2}{*}{$\begin{array}{l}\text { Ab- } \\
\text { sorbed } \\
\text { Dose } \\
\text { rate( }\left(D_{\mathrm{R}}\right) \\
(\mathrm{nGy} / \mathrm{h})\end{array}$} & \multirow{2}{*}{$\begin{array}{c}\text { Annual } \\
\text { Effective } \\
\text { Dose rate } \\
\left(\mathrm{H}_{\mathrm{R}}\right) \\
(\mathrm{mSV} / \mathrm{y})\end{array}$} & \multirow{2}{*}{$\mathrm{H}_{\text {in }}$} & \multirow{2}{*}{$\mathrm{H}_{\mathrm{ex}}$} \\
\hline & & ${ }^{226} \mathrm{Ra}$ & ${ }^{232} \mathrm{Th}$ & ${ }^{40} \mathrm{~K}$ & & & & & & \\
\hline 1 & Brick & 8.61 & 27.15 & 344.75 & 73.98 & 0.0997 & 65.36 & 0.08 & 0.22 & 0.199 \\
\hline 2 & Clay & BDL & 77.8 & 414.5 & 143.17 & 0.1927 & 118.74 & 0.145 & 0.38 & 0.386 \\
\hline 3 & Soil & 11.82 & 74.2 & 419.7 & 150.24 & 0.2023 & 126.07 & 0.154 & 0.43 & 0.405 \\
\hline 4 & Sand & 7.47 & 27.09 & 293.21 & 68.79 & 0.0927 & 60.12 & 0.073 & 0.2 & 0.185 \\
\hline 5 & Cement & 31.26 & 41.75 & 233.92 & 108.97 & 0.1468 & 93.39 & 0.114 & 0.37 & 0.294 \\
\hline \multicolumn{2}{|c|}{ AVERAGE } & 11.83 & 49.59 & 341.21 & 109.03 & 0.1468 & 92.74 & 0.113 & 0.32 & 0.294 \\
\hline
\end{tabular}

\section{Radium Equivalent Activity $\left(\mathbf{R a}_{\mathrm{eq}}\right)$}

To represent the activity levels of ${ }^{226} \mathrm{Ra},{ }^{232} \mathrm{Th}$ and ${ }^{40} \mathrm{~K}$ by a single quantity, which takes into account the radiation hazards associated with them, a common radiological index has been introduced. This index is called radium equivalent $\left(\mathrm{Ra}_{\mathrm{eq}}\right)$ activity and is mathematically defined as ${ }^{[3]}$

$\mathrm{Ra}_{\mathrm{eq}}(\mathrm{Bq} / \mathrm{kg})=\mathrm{A}_{\mathrm{Ra}}+1.43 \mathrm{~A}_{\mathrm{Th}}+0.077 \mathrm{~A}_{\mathrm{K}}$

Where $A_{R a}, A_{T h}, A_{K}$ represents the activity concentration of ${ }^{226} \mathrm{Ra},{ }^{232} \mathrm{Th}$ and ${ }^{40} \mathrm{~K}$. In the above relation, it has been assumed that $10 \mathrm{Bqkg}^{-1}$ of ${ }^{226} \mathrm{Ra}, 7 \mathrm{Bqkg}^{-1}$ of ${ }^{232} \mathrm{Th}$ and $130 \mathrm{Bqkg}^{-1}$ of ${ }^{40} \mathrm{~K}$ produce equal $\gamma$ - dose.

The recommended maximum levels of $\mathrm{Ra}_{\mathrm{eq}}$ for building materials to be used for homes and industries are $<370 \mathrm{~Bq} /$ $\mathrm{kg}$. The calculated $\mathrm{Ra}_{\mathrm{eq}}$ values range from 68.79 (sand) to 150.24 (soil) Bq/ $\mathrm{kg}$ with an average of $109.03 \mathrm{~Bq} / \mathrm{kg}$. All values of $\mathrm{Ra}_{\mathrm{eq}}$ in the studied samples are found to be lower than the criterion limit of $370 \mathrm{~Bq} / \mathrm{kg}^{[16]}$. The results of this study show that the average value of $\mathrm{Ra}_{\mathrm{eq}}$ obtained for the building materials is 109.03 $\mathrm{Bq} / \mathrm{kg}$, which is below the recommended maximum value (370 $\mathrm{Bq} / \mathrm{kg}$ ) and thus do not pose any radiological hazard when used for the construction of buildings. The table 2 shows that the comparison of radium equivalents $(\mathrm{Bq} / \mathrm{kg})$ in clay bricks, cement, sand, soil/clay in different areas of the world.Fig-1 shows the building materials variation with activity concentration and radium equivalent activity

Table 2. Comparison of radium equivalents $(\mathrm{Bq} / \mathrm{kg})$ in clay bricks, Cement, Sand, Soil/Clay in different areas of the world.

\begin{tabular}{|l|l|c|c|c|c|c|}
\hline S. No & Country & Clay bricks & Cement & Sand & Soil/ clay & Reference \\
\hline 1 & Algeria & 130 & 112 & 28 & - & {$[2]$} \\
\hline 2 & Brazil & 202.7 & 188.8 & 102 & 68.2 & {$[17]$} \\
\hline 3 & Cameroon & 193.34 & 70.1 & 104 & - & {$[18]$} \\
\hline 4 & China & 201.9 & 127.7 & 94.7 & - & {$[19]$} \\
\hline 5 & Cuba & 134.6 & 73.9 & 53.5 & - & {$[20]$} \\
\hline 6 & Jordan & - & - & 86.22 & - & {$[21]$} \\
\hline 7 & NWFP & - & - & - & 122 & {$[22-23]$} \\
\hline 8 & $\begin{array}{l}\text { Bahawalpur } \\
\text { division }\end{array}$ & - & - & - & 158.5 & {$[24]$} \\
\hline 9 & Punjab & - & - & - & 141 & {$[25]$} \\
\hline 10 & Paschal & 73.98 & 108.97 & 68.79 & 150.24 & Present work \\
\hline
\end{tabular}




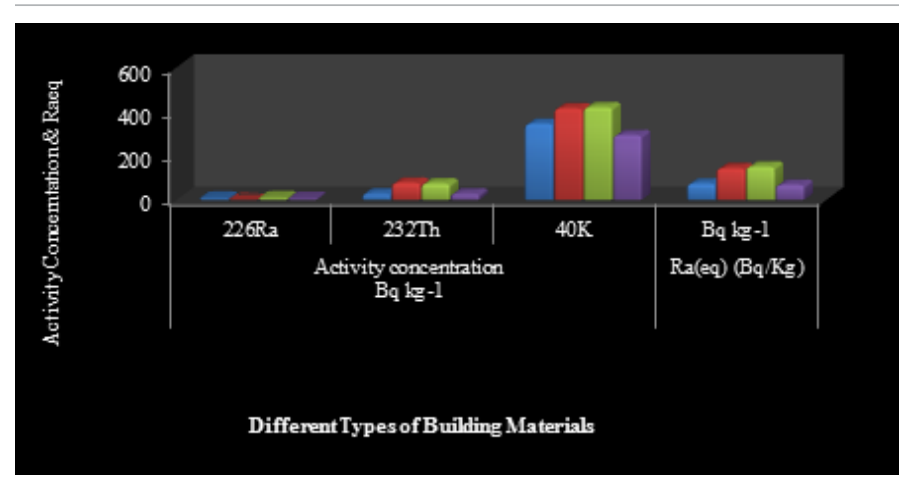

Figure.1 Different types of Building Materials Vs Activity Concentration (Bg/ $\mathrm{kg}) \& \mathrm{Ra}_{\mathrm{eq}}(\mathrm{Bg} / \mathrm{kg})$

\section{Criteria Formula (CF)}

Based on models suggested by Krisiuk et $\mathrm{al}^{[26]}$ and Stranden ${ }^{[27]}$, a value of $1.5 \mathrm{mGy}$ was obtained by Krieger ${ }^{[28]}$ when evaluating the annual external radiation dose inside dwellings constructed of building materials with a $\mathrm{Ra}_{\text {eq }}$ value of $370 \mathrm{~Bq} / \mathrm{kg}$. These authors later corrected their calculations by taking into consideration a wall of finite thickness and applying a weighing factor of $0.7^{[29]}$ to account for the presence of windows and doors. Their results can be used as a criterion to limit the annual radiation dose from building materials based on the following formula:

$C F=\frac{A_{R a}}{740}+\frac{A_{T h}}{520}+\frac{A_{K}}{9620}<1$

Where $A_{R a}, A_{T h}$ and $A_{K}$ are the activities of ${ }^{226} \mathrm{Ra},{ }^{232} \mathrm{Th}$ and ${ }^{40} \mathrm{~K}$, respectively in building materials in units of $\mathrm{Bq} / \mathrm{kg}$. The corresponding values calculated from the sum of the three quotients for the annual radiation dose associated with the studied building materials are given in Table-1. The values of criteria formula are ranging from 0.0927 (sand) to 0.2023 (soil) with an average of 0.1468 . The average value $(0.1468)$ of the studied samples is below the recommended maximum value $(<1)$. This indicates that gamma activity in the building materials does not exceed the proposed criterion level and safely used for constructions. Fig- 2 shows the various types of building materials and the criteria formula.

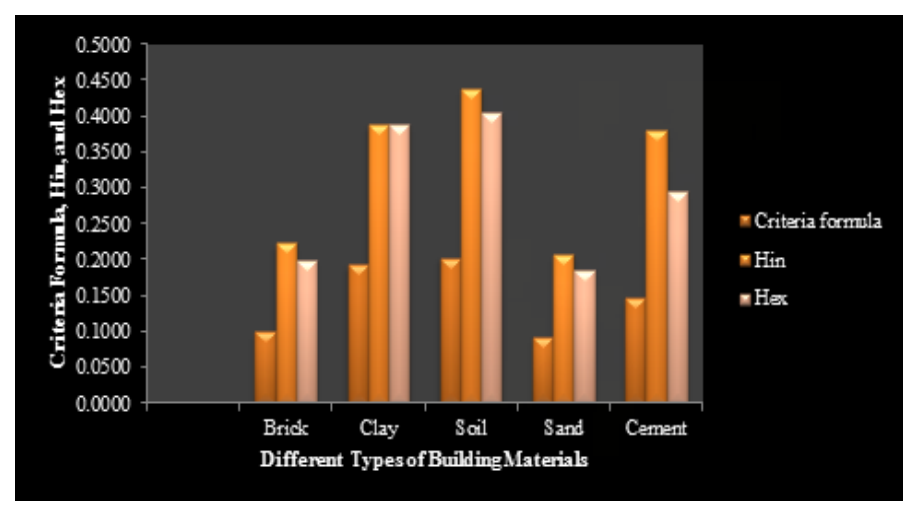

Figure 2: Different types of Building Materials Vs Criteria formula, $\mathrm{H}_{\mathrm{in}}$ and $\mathrm{H}_{\mathrm{ex}}$

\section{Estimation of Absorbed Gamma Dose Rate $\left(D_{R}\right)$ and Annual Effective Dose Rate $\left(\mathrm{H}_{\mathrm{R}}\right)$}

The absorbed dose rates in indoor air $\left(\mathrm{D}_{\mathrm{R}}\right)$ and the corresponding annual effective doses $\left(\mathrm{H}_{\mathrm{R}}\right)$ attributed to gamma-ray emission from the radio nuclides $\left({ }^{226} \mathrm{Ra},{ }^{232} \mathrm{Th}\right.$ and $\left.{ }^{40} \mathrm{~K}\right)$ in building materials were evaluated using data and formulae provided by UNSCEAR ${ }^{[30]}$ and the $\mathrm{EC}^{[31]}$. In the UNSCEAR and European Commission reports, the dose conversion coefficients were calculated for the center of a standard room. The dimensions of this room are $4 \mathrm{~m} \times 5 \mathrm{~m} \times 2.8 \mathrm{~m}$. The thickness of the walls, floors and ceiling and the density of the structure are $20 \mathrm{~cm}$ and 2350 $\mathrm{kg} \mathrm{m}^{-3}$ (concrete), respectively. The resulting dose coefficients were found to be $0.92 \mathrm{nGy} \mathrm{h}^{-1}$ per Bq/kg for ${ }^{226} \mathrm{Ra}, 1.1 \mathrm{nGy} \mathrm{h}^{-1}$ per $\mathrm{Bq} / \mathrm{kg}$ for ${ }^{232} \mathrm{Th}$ and $0.080 \mathrm{nGy} \mathrm{h}^{-1}$ per $\mathrm{Bq} / \mathrm{kg}$ for ${ }^{40} \mathrm{~K}$.

$\mathrm{D}_{\mathrm{R}}\left(\mathrm{nGyh}^{-1}\right)=0.92 \times \mathrm{A}_{\mathrm{Ra}}+1.1 \times \mathrm{A}_{\mathrm{Th}}+0.080 \times \mathrm{A}_{\mathrm{K}}$------ (3)

Where $A_{R a}$ is the activity concentration of ${ }^{226} \mathrm{Ra}, \mathrm{A}_{\mathrm{Th}}$ is the activity concentration of ${ }^{232} \mathrm{Th}$, and $\mathrm{A}_{\mathrm{K}}$ is the activity concentration of ${ }^{40} \mathrm{~K}$ in units of $\mathrm{Bq} / \mathrm{kg}$.

To estimate the annual effective dose rate, it is necessary to use the conversion coefficient from the absorbed dose in air to the effective dose $\left(0.7 \mathrm{~Sv} \mathrm{~Gy}^{-1}\right)$ and the outdoor occupancy factor $\left(0.2 \mathrm{~Sv} \mathrm{~Gy}^{-1}\right)$ proposed by UNSCEAR ${ }^{[30]}$. Therefore, the effective dose rate is determined as follows:

Outdoor $\left(\mathrm{mSv} \mathrm{y}^{-1}\right)=\mathrm{D}_{\mathrm{R}}\left(\mathrm{nGy} \mathrm{h}^{-1}\right) \times 24 \mathrm{~h} \times 365.25 \mathrm{~d} \times 0.2$ (outdoor occupancy factor) $\times 0.7 \mathrm{~Sv} \mathrm{~Gy}^{-1}$ (conversion factor) $\times 10^{-6}$

$\mathrm{H}_{\mathrm{R}}=\mathrm{D}_{\mathrm{R}} \times 8766 \times 0.2 \times 0.7 \times 10^{-6}=\mathrm{D}_{\mathrm{R}} 00123$------- (4)

Where $D_{R}\left(n G y h^{-1}\right)$ is given by Eq. (3). The estimated result for $D_{R}$ and for $H_{R}$ is given in Table 1. The estimated $D_{R}$ and $H_{R}$ values for all the studied building materials range from 60.128 (sand) to 126.070 (soil) in $\mathrm{nGy} \mathrm{h}^{-1}$ and 0.0737 (Sand) to 0.1546 (soil) in $\mathrm{mSv} \mathrm{y}^{-1}$ respectively. From the data in Table-1, the estimated mean value of $D_{R}$ in the studied samples is 92.74 $n G y h^{-1}$, which is slightly higher than world average (populated- weighted) indoor absorbed gamma dose rate of $84 \mathrm{nGy} \mathrm{h}^{-1}$. Additionally, the estimated mean value of the annual effective dose rate of $0.1137 \mathrm{mSv} \mathrm{y}^{-1}$ is less than the permissible limit. Figs. $3 \& 4$ shows that the various types of building materials along with the absorbed dose rate and the annual effective dose rate respectively.

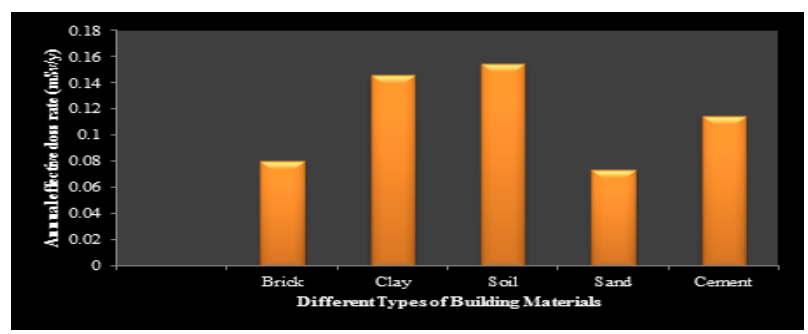

Figure 3: Different types of Building Materials Vs Absorbed Doss Rate (nGy/h)

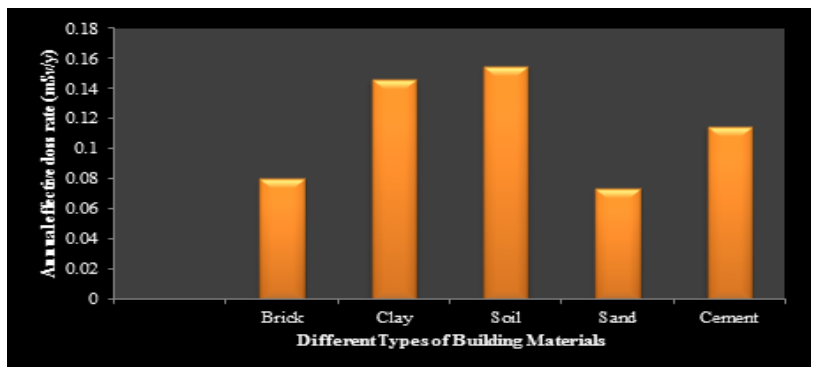

Figure 4: Different types of Building Materials Vs Annual effective doss rate $(\mathrm{mSv} / \mathrm{y})$ 


\section{Radiation hazard indices}

Beretka and Mathew ${ }^{[3]}$ defined the two indices that represent (i) the internal radiation hazard, $\mathrm{H}_{\text {in }}$ (ii) the external radiation hazard, $\mathrm{H}_{\mathrm{ex}}$, which are discussed in this section.

\section{Internal Radiation hazard index $\left(\mathrm{H}_{\text {in }}\right)$}

In addition to the external radiation hazard they pose radon and its short-lived daughters are also hazardous to the respiratory organs. The internal exposure caused by radon and its daughter products is quantified by the internal hazard index $\mathrm{H}_{\text {in }}$, which has been defined as shown below:

$H_{i n}=\frac{A_{R a}}{185 B q / k g}+\frac{A_{T h}}{259 B q / k g}+\frac{A_{k}}{4810 B q / k g}-----(5)$

The internal hazard index is defined to reduce the acceptable maximum concentration of ${ }^{226} \mathrm{Ra}$ to half the value appropriate to external exposure alone. For the safe use of materials in the construction of dwellings, the following criterion was proposed by Krieger ${ }^{[28]}$

$\mathrm{H}_{\text {in }} \leq 1$---- $(6)$

The mean value of $\mathrm{H}_{\text {in }}$ is determined to be 0.32 which is $<1$, indicating that the internal hazard is below the critical value and it indicates that the materials are free from radiation hazards. Fig-2 shows the various types of building materials and internal radiation hazard $\mathrm{H}_{\text {in }}$.

\section{External Radiation hazard index $\left(\mathrm{H}_{\mathrm{ex}}\right)$}

The external hazard index is an additional criterion to assess the radiological suitability of a material. It is defined as follows:

$$
H_{e x}=\frac{A_{R a}}{370 B q / k g}+\frac{A_{T h}}{259 B q / k g}+\frac{A_{k}}{4810 B q / k g} \leq 1-----(7)
$$

Where $A_{\text {Ra }}, A_{T h}$ and $A_{K}$ are the activities of ${ }^{226} \mathrm{Ra},{ }^{232} \mathrm{Th}$ and ${ }^{40} \mathrm{~K}$ respectively in units of $\mathrm{Bq} / \mathrm{kg}$. The value of this index should be less than unity for the radiation hazard is to be negligible, i.e., for the radiation exposure attributed to radioactivity in construction materials to be limited to $1.50 \mathrm{mSv}^{-1}$. The mean value 0.29 of $\mathrm{H}_{\mathrm{ex}}$ is below the criterion value $(<1)$ indicates that no significant radiation hazards of building materials. Fig-2 shows the various types of building materials and External radiation hazard index $\mathrm{H}_{\mathrm{ex}}$.

\section{Conclusion}

The natural radionuclide activity content, radium equivalent activity, the criteria formula, the absorbed gamma dose rate in indoor air and the corresponding annual effective dose, the external and internal hazard indices of some building materials commonly used in Pachal village of Tiruvannamalai district, Tamilnadu, India, were determined. All the health hazard indices are well below their recommended limits. The building materials investigated in this study can be safely used as building material for dwelling construction. The obtained data could be useful as base line data for radiation assessment in building materials.

\section{Acknowledgment}

One of the author (R. Ravisankar) wishes to express his high gratitude to Dr. B. Venkatraman, AD, RSEG, Indira Gandhi Centre for Atomic Research (IGCAR), Kalpakkam, Tamilnadu for giving his permission to use the nuclear counting facility in RSD and also Mr. R. Mathiarasu, Scientific Officer, RSD, IGCAR, Kalpakam, India for his technical help in counting the samples. Our special thanks to Dr. M.T. Jose, Head, RSD, IGCAR for his keen help, constant encouragements in Gamma ray spectroscopic measurements.

\section{Reference}

1. Ahmad, N., Matiullah Hussain, A.J.A. Natural radioactivity in Jordan soil and building materials and the associated radiation hazards. (1988) J Environ Radioact 39(1): 9-22.

2. Amrani, D., Tahtat, M. Natural radioactivity in Algerian building materials. (2001) Appl Radiat Isot 54 (4): 687-689.

3. Beretka, J., Mathew, P.J. Natural radioactivity of Australian building materials, industrial wastes and by-products. (1985) Health Phys 48(1): 87-95.

4. Chong, C.S., Ahmad, G.U. Gamma activity of some building materials in West Malaysia. (1982) Health Phys 43(2): 272-273.

5. Mollah, A.S., Ahmad, G.U., Husain, S.R., et al. The natural radioactivity of some building materials used in Bangladesh. (1986) Health Phys 50(6): 849-851.

6. Kumar, V., Ramachandran, T.V., Prasad, R. Natural radioactivity of Indian building materials and by-products. (1999) Appl Radiat Isot 51(1): 93-96.

7. Zaidi, J.H., Arif, M., Ahamed, S., et al. Determination of natural radioactivity in building materials used in the Rawalpindi/Islamabad area by gamma ray spectrometry and instrumental neutron activation analysis. (1999) Appl Radiat Isot 51(5): 559-564.

8. El-Arabi, A.M. Natural Radioactivity in sand and in thermal therapy at the Red Sea Coasts. (2005) J Environ Radioact 81(1): 11-19.

9. El-Tahawy, M.S., Higgy, R.H. Natural radioactivity in different types of bricks fabricated and used in Cario region.(1995) Appl Radiat Isot 46(12): 1401-1406.

10. Khan, K., Khan, H.M. Natural gamma emitting radionuclides in Pakistani Portland cement. (2001) Appl Radiat Isot 54(5): 861-865.

11. Ravisankar, R., Vanasundari, K., Chandrasekaran, A., et al. Measurement of natural radioactivity in building materials of Namakkal, Tamilnadu, India using gamma ray spectrometry. (2012) Appl Radiat Isot 70(4): 699-704.

12. Ravisankar, R., Vanasundari, K., Chandrasekaran, A., et al. Measurement of Natural radioactivity in brick samples of Namakkal, Tamilnadu, India using gamma ray spectrometry. (2011) Arch Physics Res 2(2): 95-99.

13. Ravisankar, R., Vanasundari, K., Chandrasekaran, A., et al. Multivariate statistical analysis of radiological data of building materials used in Tiruvannamalai, Tamilnadu, India. (2014) Appl Radiat Isot 85: $114-127$.

14. Kumar, A., Kumar, M., Singh, B., et al. Natural activities of $238 \mathrm{U}$, $232 \mathrm{Th}$ and $40 \mathrm{~K}$ in some Indian building materials. (2003) Radiat Meas 36(1-6): 465-469.

15. NageswaraRao, M. V., Bhatti, S.S., Rama Seshu, P., et al. Natural radioactivity in soil and radiation levels of Rajasthan. (1996) Radiat Prot Dosim 63(3): 207-216.

16. NEA-OECD. Exposure to radiation from natural radioactivity in building materials. (1979) Report by NEA group of Experts of the Nuclear Energy Agency.

17. Malanca, A., Passina, V., Dallara, G. Radionuclide content of building materials and gammaray dose rates in dwellings of Rio-Grande DoNorte Brazil. (1993) Radiat Prot Dosim 48(2): 199-203.

18. Ngachin, M., Garavaglia, M., Giovani, C., et al. Assessment of natural radioactivity and associated radiation hazards in some Cameroonian building materials. (2007) Radiat Meas 42(1): 61-67. 
19. Xinwei, L. Natural radioactivity in some building materials and byproducts of Shaanxi. China. (2004) J Radianal Nucl Chem 262(3): $775-777$.

20. Flores, O. B., Estrada, A. M., Zerquera, J. T. Natural radioactivity in some building materials in Cuba and their contribution to the indoor gamma dose rate. (2005) Radiat Prot Dosim 113(2): 218-222.

21. Al-Jundi, J., Salah, W., Bawa'aneh, M. S., et al. Exposure to radiation from the natural radioactivity in Jordanian building materials. (2005) Radiat Prot Dosim 118(1): 93-96.

22. Rahman, S., Matiullah, Mujahid, S. A., et al. Assessment of the radiological hazards due to naturally occurring radionuclides in soil samples collected from the North Western area of Pakistan. (2007) Radiat Prot Dosim 128(2): 191-197.

23. Ali, A., Orfi, S.D., Qureshi, A.A. Assessment of the natural radioactivity and its radiological hazards in Shewa-ShahbazGarhi igneous complex, Peshawar plain, NW Pakistan. (2002) Health Phys 82(1): 74-79.

24. Matiullah., Ahad, A., Rehman, S., et al. Measurement of Radioactivity in the Soil of Bahawalpur Division, Pakistan. (2004) Radiat Prot Dosim 112(3): 443-447.
25. Tahir, S.N., Jamil, K., Zaidi, J. H., et al. Measurements of activity concentrations of naturally occurring radionuclides in soil samples from Punjab province of Pakistan and assessment of radiological hazards. (2005) Rad Prot Dosim 113(4): 421-427.

26. Krisiuk, E.M., Tarasov, S. I., Shamov, V. P., et al. A Study of Radioactivity in Building Materials. (1971) Research Institute of Radiation Hygeine Leningrad. 1971.

27. Stranden, E. Some aspects on radioactivity of building materials. (1976) Phys Norv 8: 167-173.

28. Krieger, R. Radioactivity of construction materials. (1981) Betonwerk Fertigteil Techn 47(8): 468-473.

29. Keller, G., Muth, H. Natural radioadiation exposure an medical radiology: In. In: E. Scherer, C.h. Streffer, K.R. Tolt, (Eds.). (1990) Radiation Exposure and Occupational Risks. Springer-Verlag, Berlin.

30. UNSCEAR. Sources and Risks of Ionizing Radiation. (2000) Report to the General Assembly with annexes.

31. EC (European Commission), Radiation Protection112- Radiological Protection Principles Concerning the Natural Radioactivity of Building Materials. (1999) Directorate-General Environment, Nuclear Safety and Civil Protection. 